\title{
An Analysis of the Welfare Effect of RMB and ASEAN Countries' Currency Foreign Exchange Market Construction
}

\author{
Yonghua Yang ${ }^{\mathrm{a}}$ and Ying Chen ${ }^{\mathrm{b}}$ \\ School of Economics and Management, Yunnan Normal University, Kunming 650500, China \\ ayhyang2003@163.com, b2508428618@qq.com
}

\begin{abstract}
This paper analyzes the welfare effect of RMB and ASEAN countries' foreign exchange market from the perspective of state and participant. RMB and ASEAN countries currency foreign exchange market construction is conducive to the formation of China - ASEAN monetary union, or the RMB in the ASEAN countries regionalization. China's exchange rate stability, internationalization of the RMB, international direct investment, enterprises and residents have had a certain impact.
\end{abstract}

Keywords: Foreign exchange market, welfare effect, RMB internationalization.

\section{Introduction}

China in recent years, the economic crisis in the appropriate adjustment of the national fiscal policy and monetary policy, with China's international status in the increase, more and more countries began to use the yuan. In the border trade between the Democratic People's Republic of Korea, Russia, Pakistan, Mongolia and Thailand, Laos, Myanmar, Malaysia, Cambodia, the Philippines, Vietnam and other ASEAN countries, more and more people are willing to use RMB as clearing or paying the currency. In addition, China Taiwan, Hong Kong and Vietnam and other places, many tourist shops also use RMB to trade. At present, China's foreign exchange market is prone to a daily limit, the daily limit of the phenomenon, mainly because of the development of China's foreign exchange market is not perfect, the RMB circulation is insufficient, and the RMB and ASEAN countries foreign currency market construction has increased the RMB in the international circulation, from the breadth and depth On the promotion of China's foreign exchange market to further develop the country and the participants played a positive role.

\section{RMB and ASEAN countries currency foreign exchange market construction on the country's impact}

\subsection{RMB and ASEAN countries currency foreign exchange market construction on China's exchange rate stability}

At present, the RMB in the world, especially in the ASEAN countries or regions more and more widely used in the offshore market, RMB foreign exchange trading volume has exceeded the onshore market, cross-border RMB business development more and more. Due to the constraints on the onshore market, the price and trading mechanism is not flexible enough, the market participants are not fully involved. The establishment of a certain breadth and depth of the RMB and the ASEAN currency foreign exchange market, is to improve the market-oriented exchange rate formation mechanism of the objective needs, and China's exchange rate stability have some impact: To improve the RMB exchange rate formation mechanism, broaden the RMB international market base; Innovative foreign currency on the market, the direct establishment of the international foreign exchange market links; To meet the needs of the market, innovation and the introduction of RMB exchange rate derivatives and foreign exchange transactions of new varieties.

Since 2005, the RMB exchange rate formation mechanism has been in accordance with the principle of initiative, progressive, controllable principle in order to advance, in general, China's real economy has played a positive impact. The international financial crisis, to the Chinese economy to 
bring a certain negative impact, but also to the internationalization of the RMB has brought opportunities. RMB and ASEAN countries, the construction of currency foreign exchange market will further promote the RMB exchange rate formation mechanism reform, enhance the RMB exchange rate flexibility. The increase in the circulation of RMB and the expansion of the scope of circulation will affect China's exchange rate in a reasonable, balanced water to maintain basic stability, to promote the balance of payments balance, maintaining macroeconomic and financial market stability.

\subsection{RMB and ASEAN countries currency foreign exchange market construction on the internationalization of RMB}

With the formation of the RMB and foreign currency foreign exchange market, the foreign exchange market of China has been growing and gradually established a floating RMB exchange rate system based on market supply and demand. According to the principle of initiative, graduality and controllability, I step by step progressive development. Now, in the changing situation at home and abroad, not only for China's macroeconomic regulation and control of economic entities to create the conditions, but also played a positive role in the RMB internationalization, providing a certain system guarantee.

RMB and ASEAN countries currency foreign exchange market construction, can make the internationalization of the RMB to play a positive external network effect. Whether the currency is accepted and is willing to accept the extent of its traders and its circulation. Currency functions are different, the network effect is different, especially the trading function. The theory of network externality is a kind of monetary substitution theory. From the point of view of network externality theory, the currency conversion mechanism, the cooperative mechanism and the supporting mechanism constitute the RMB internationalization mechanism. Including the internal aspects of the currency conversion mechanism and the coordination mechanism for the internationalization of the RMB to provide power; external, the support mechanism for the internationalization of the RMB to provide support. With the RMB in foreign exchange reserves and trade and investment continue to use, the internationalization of the RMB to play the positive externalities of the network effect is gradually expanding. In the RMB and ASEAN countries currency foreign exchange transactions, to the RMB to bring path dependence, to increase the number of traders using the RMB, to expand the scope of the RMB circulation, and can reduce transaction costs, so that people tend to use the RMB.

\subsection{RMB and ASEAN countries currency foreign exchange market construction on the impact} of international direct investment

RMB and ASEAN countries currency foreign exchange market construction through the following three aspects affect the international direct investment:

Reducing the relative cost of production of exchange rate movements affects international direct investment. The traditional theory of international investment mainly focuses on the motivations and abilities of foreign investment in multinational corporations, and the influence of exchange rate and its changes on FDI has long been neglected. The relative cost theory of exchange rate changes argues that when the home currency is appreciating relative to the host country, the prices of the assets, raw material prices and nominal wages of the host country are relatively lower than those of the home country, since, for the home country of the international direct investment, The same amount of investment can be purchased in the host country to buy more assets, more production materials, hire more labor, that is, to reduce the foreign investment enterprises in the host country's production and operating costs, improve the rate of return on capital will promote Foreign direct investment in the host country against the host country. On the contrary, if the country's currency relative to the depreciation of the host country, the host country's assets, raw material prices and nominal wages relative to the home price increases, the home currency price of the same amount of investment can be purchased in the host assets, more production materials, The decline in the number of labor force employed, the increase in the production and operating costs of foreign investment enterprises in the host country will reduce the home country's international direct investment in the host country. A country's foreign direct investment fluctuates with the exchange rate between the home currency and 
the host currency. RMB and ASEAN countries The currency foreign exchange market construction is conducive to the formation of China-ASEAN monetary union, or the regionalization of RMB in ASEAN countries, the formation of China-ASEAN monetary union or the regionalization of RMB in ASEAN countries is conducive to the elimination or reduction of this region Exchange rate fluctuations, and promote direct investment in the region.

The Impact of RMB Regionalization on Foreign Direct Investment. RMB regionalization can reduce the financing costs of foreign investment enterprises. RMB regionalization can reduce the foreign investment enterprises purchase costs and exchange rate risk. RMB regionalization is conducive to promoting China's financial institutions "going out" to improve the competitiveness of the financial system.

The Impact of RMB and ASEAN Countries' Foreign Currency Market Construction on International Trade. First of all, the formation of China-ASEAN monetary union or the regionalization of RMB in ASEAN countries will promote the development of border trade in China. Second, the formation of the China-ASEAN Monetary Union or the regionalization of the RMB in the ASEAN countries will promote the risk of reducing exchange rate fluctuations and expand the scope and scale of foreign trade. Again, the formation of China-ASEAN monetary union or regionalization of RMB in ASEAN countries can reduce transaction costs and expand the scale of trade. The use of common currency can reduce transaction costs, both of which can promote the increase in trade.

China's foreign trade enterprises in the settlement, settlement and other business, the need to pay a certain amount of fees to the bank, wire transfer fees and other costs, although the amount is not very large amount, but for some profitable enterprises, this is a sum Not a small burden. If the RMB in the ASEAN countries to achieve regionalization or the formation of monetary union, China's foreign trade enterprises can directly use the RMB for international trade pricing and settlement, which will transaction costs. Compared with the EU, China and ASEAN countries have the advantages of trade between the geographical position, China and ASEAN countries in the economic development process, mutual trade continues to increase. As the distance between East Asian countries is relatively close, the transportation cost is relatively low in the process of trade. With the continuous development of national economy, different monetary policies and exchange rate policies affect the trade between countries. The common currency between China and ASEAN Use can reduce the exchange rate changes, while the common currency can reduce the transaction costs and thus have a positive effect on trade.

\section{RMB and the ASEAN countries' currency foreign exchange market construction on the foreign exchange market participants}

\subsection{An Analysis of the Impact of RMB and ASEAN Countries' Foreign Currency Market Construction on Enterprises}

RMB and ASEAN countries, the construction of currency foreign exchange market on the one hand makes the choice of currency on the market more choice, the two sides in the contract can be negotiated to choose their own favorable currency, in order to avoid trading risks. Try to keep the assets and liabilities of the currency match, in order to avoid accounting risk. On the other hand, diversification of trading tools, so that both companies in the trade and investment can be combined with their own purpose to choose the appropriate trading tools and settlement methods to pass on risk, hedge or profit. At the same time according to the settlement currency exchange rate to determine the settlement time in order to avoid the risk. The construction of China's ASEAN foreign exchange market provides enterprises with more choices to resist foreign exchange risk, enabling enterprises to more effectively control their risks while focusing on their own production and business activities to achieve greater returns. 


\subsection{An Analysis of the Impact of RMB and ASEAN Countries' Foreign Currency Market Construction on Residents}

China and ASEAN countries currency exchange more convenient. Foreign exchange market product investment is more active. RMB and ASEAN countries, the construction of currency foreign exchange market, on the one hand makes the two sides in the currency exchange, you can save the conversion into third-party currency procedures, choose their own more favorable currency or directly to the currency exchange, transaction costs, The exchange process is more convenient and effective. On the other hand makes the price of the two currencies more transparent and transparent in front of people, to avoid the "spread of the bank," the risks brought about by the transaction, while helping to curb the interests of individuals arising from the phenomenon of individual spin-off, Market, so that the healthy and orderly development of the future economic and trade exchanges between the two sides more useful. For the ASEAN countries, the RMB has been widely accepted, the RMB and ASEAN countries, the construction of foreign currency market will greatly increase China's trade and investment in ASEAN countries, is conducive to the two sides to re-allocation of resources. China and ASEAN in the export structure of the competitive and complementary, the opening of the foreign exchange market will increase the pressure on enterprises, thanks to its natural resources, the local tourism industry will vigorously develop for the local residents to bring better employment opportunities and Life security.

\section{Conclusion}

RMB and ASEAN countries The currency foreign exchange market construction will facilitate the exchange of different currencies of China and ASEAN countries, promote the smooth realization of international trade, provide buyer, seller credit and guarantee, promote the continuous expansion of international trade scale and the normal flow of funds of importers and exporters, To maintain foreign exchange balance, to avoid foreign exchange risk to provide tools. RMB and ASEAN countries currency foreign exchange market construction is conducive to the formation of China - ASEAN monetary union, or the RMB in the ASEAN countries regionalization. The formation of China-ASEAN monetary union or the regionalization of the RMB in the ASEAN countries is conducive to eliminating or reducing the exchange rate fluctuations in the region and promoting the regionalization and internationalization of the RMB in this region, thereby promoting foreign direct investment and foreign trade in the region, On the enterprise settlement, foreign exchange market tool selection, foreign exchange risk management have an impact, but also on the residents of foreign exchange, foreign exchange market, such as investment products have an impact.

\section{Acknowledgments}

This research is supported by Natural Science Foundation of China (No.71363064) and the project of Philosophy and Social Science Research of Yunnan Province (No.JD2015YB23).

\section{References}

[1] Alejandro Micco, Ernesto Stein, Guillermo Ordonez.2003. "The Currency Union Effect on Trade Early Evidence from EMU".

[2] Jelle Brouwer and Jean-Marie Viaene.2006. "The Trade and FDI Effects of EMU Enlargement".

[3] Aleksander Aristovnik and Matevz Meze.2010. "The Economic and Monetary Union's Effect on Trade: the case of Slovenia before Euro Adoption".

[4] Mizanur Rahman.2008. "The Impact of a Common Currency on East Asian Production Networks and China's Exports Behavior". 